\title{
In vitro pharmacological characterization of a novel TRPAI antagonist and proof of mechanism in a human dental pulp model
}

This article was published in the following Dove Press journal: Journal of Pain Research

29 January 2013

Number of times this article has been viewed

\author{
Eva Nyman ${ }^{1, *}$ \\ Bo Franzén 1,* \\ Andreas Nolting' \\ Göran Klement' \\ Gang Liu' \\ Maria Nilsson' \\ Annika Rosén ${ }^{2}$ \\ Charlotta Björk ${ }^{3}$ \\ Dirk Weigelt ${ }^{4}$ \\ Patrik Wollberg' \\ Paul Karila' \\ Patrick Raboisson'
}

'Neuroscience, Innovative Medicines CNS/Pain, AstraZeneca R\&D,

Södertälje, Sweden; ${ }^{2}$ Division of Oral and Maxillofacial Surgery, Karolinska Institute/Karolinska University Hospital, Huddinge, Sweden; ${ }^{3}$ Clinical TA NS Early Development, ${ }^{4}$ Medicinal Chemistry, Innovative Medicines CNS/ Pain, AstraZeneca R\&D, Södertälje, Sweden

*These authors contributed equally to this work
Correspondence: Eva Nyman AstraZeneca R\&D Södertälje, SE-I5I 85 Sodertalje, Sweden Tel +46707203254

Email eva_nyman@telia.com
Abstract: AZ465 is a novel selective transient receptor potential cation channel, member A1 (TRPA1) antagonist identified during a focused drug discovery effort. In vitro, AZ465 fully inhibits activation by zinc, $O$-chlorobenzylidene malononitrile (CS), or cinnamaldehyde of the human TRPA1 channel heterologously expressed in human embryonic kidney cells. Our data using patch-clamp recordings and mouse/human TRPA1 chimeras suggest that AZ465 binds reversibly in the pore region of the human TRPA1 channel. Finally, in an ex vivo model measuring TRPA1 agonist-stimulated release of neuropeptides from human dental pulp biopsies, AZD465 was able to block $50 \%-60 \%$ of CS-induced calcitonin gene-related peptide release, confirming that AZ465 inhibits the native human TRPA1 channel in neuronal tissue.

Keywords: pain, pharmacology, antagonist, chimeric proteins, dental pulp, inflammation, neuropeptide, calcitonin gene-related peptide, CGRP

\section{Introduction}

The transient receptor potential cation channel, member A1 (TRPA1), is a cation-permeable channel belonging to the TRP channel superfamily, which has emerged as an important molecular target for several types of pain and inflammatory conditions. TRPA1 is highly expressed in sensory neurons in dorsal root ganglia and trigeminal ganglia, where it colocalizes with another TRP channel, TRPV $1,{ }^{1,2}$ and acts as a cellular sensor for various stimuli. TRPA1 is reported to be activated by noxious cold, ${ }^{3}$ some divalent ions (eg, $\mathrm{Ca}^{2+}$ $\left.\mathrm{Zn}^{2+}\right)$, 4,5 and by a number of exogenous electrophilic compounds, such as the pungent ingredients in mustard oil (allyl isothiocyanate), ginger, cinnamon oil (cinnamaldehyde), ${ }^{6,7}$ garlic (allicin), ${ }^{8}$ and various tear gases ${ }^{9}$ (eg, $O$-chlorobenzylidene malononitrile [CS]), all of which can induce nocifensive behaviors, burning pain sensation, and sensory neuron sensitization in animals and man (see review in Radresa et $\mathrm{al}^{10}$ ). In addition to being gated by exogenous noxious chemicals, TRPA 1 also responds to a variety of endogenous reactive compounds involved in oxidative stress and inflammation, such as 4-hydroxynonenal, ${ }^{11}$ hydrogen peroxide, ${ }^{12}$ and nitrooleic acid. ${ }^{13}$ Conversely, treatment with TRPA1 inhibitors reduces signs of hypersensitivity in various rodent models of inflammatory pain (see review in Radresa et $\mathrm{al}^{10}$ ). For instance, antagonism by the TRPA1 inhibitors HC-030031 and A-967079 completely blocked mechanical and cold hyperalgesia induced by intraplantar injection of Freund's complete adjuvant ${ }^{14,15}$ and intrathecal injection of AP-18 reduced systemic hyperalgesia induced by the major proinflammatory cytokine tumor necrosis factor alpha (TNF $\alpha){ }^{16,17}$ Recently, the role of TRPA1 in pain was further strengthened by the discovery that a gain-of-function mutation of the channel is linked to a chronic human pain syndrome - familial episodic pain syndrome. ${ }^{18}$ 
The strength of evidence supporting TRPA 1 as an attractive target against which to develop novel analgesics has led the pharmaceutical industry to invest in drug-discovery programs to identify TRPA1 antagonists. However, only a limited number of small molecules have been described in literature and patents so far. One possible contributing factor to the paucity of drug candidates is the cross-species difference in TRPA1 pharmacology; discrete variations in amino acid sequence results in key pharmacological and functional differences between TRPA1 orthologs. For instance, substances identified as antagonists at the human isoform showed no or opposite pharmacology at the rat receptor, ${ }^{19-21}$ highlighting the critical importance in drug-discovery programs aiming at TRPA 1 of choosing the right surrogate species and developing ex vivo pharmacodynamic models using relevant human tissue.

In this respect, the dental pulp presents several advantages. Composed of various cell types, including odontoblasts, fibroblasts, inflammatory cells, vascular cells, and sensory neurons (unmyelinated C- and small-diameter myelinated $\mathrm{A} \delta$-fibers containing neuropeptides such as substance $\mathrm{P}$ and calcitonin gene-related peptide [CGRP]), it constitutes a readily accessible neurological human tissue for ex vivo use that expresses TRPA $1 .{ }^{22}$ Recently, Fehrenbacher et $\mathrm{al}^{23}$ developed an ex vivo model where CGRP release from human dental pulp following exposure to capsaicin was measured and could be blocked in a concentrationdependent manner by specific TRPV1 antagonists. Since TRPA1 activation has also been shown to trigger the release of neuropeptides from peripheral (meningeal) sensory neurons,${ }^{24}$ we undertook to set up an adaptation of Fehrenbacher et al's human dental pulp model ${ }^{23}$ for the study of TRPA1 antagonists.

AZ465, a novel potent TRPA1 antagonist, was identified during a focused drug-discovery program at AstraZeneca R\&D (Södertälje, Sweden). We describe herein AZ465's in vitro pharmacological profile and binding characteristics. In addition, our data using AZD465 suggest that measuring the release of CGRP from human dental pulp can be used as an ex vivo model system to study the inhibitory effects of TRPA1 antagonists in humans.

\section{Materials and methods}

\section{Chemicals}

AZ465 ((R)- N-(1-(4-cyanophenyl)-3,3-dimethyl-1-oxobutan-2-yl)-4-(6-methylpyridin-2-yl)piperazine-1-carboxamide; Figure 1) was synthesized at AstraZeneca R\&D Södertälje (for details, see published patent application WO2012050512, where AZ465 is identified as “Formula [I]"). ${ }^{25}$
CS was manufactured at AstraZeneca Pharmaceutical Development (Bangalore, India). HC-030031 was purchased from TOSLab (Ekaterinburg, Russia). The Frescati antibody was manufactured by Agrisera (Vännäs, Sweden) for AstraZeneca exclusively.

Dulbecco's modified Eagle's medium (DMEM) with GlutaMax, Hanks' balanced salt solution with and without out $\mathrm{Ca}^{2+}$ and $\mathrm{Mg}^{2}$, and $\mathrm{NaHCO}_{3}$ were purchased from Life Technologies (Carlsbad, CA). Fetal calf serum (FCS) was purchased from HyClone (Logan, UT). Doxycycline was purchased from BD Biosciences (Franklin Lakes, NJ). Zinc chloride, HEPES (4-[2-hydroxyethyl]-1-piperazineethanesulfonic acid), trans-cinnamaldehyde, allyl isothiocyanate, $\mathrm{NaOH}, \mathrm{MgCl}_{2}, \mathrm{KCl}, \mathrm{NaCl}$, and EGTA were purchased from Sigma-Aldrich (St Louis, $\mathrm{MO}$ ). $\mathrm{CaCl}^{2}$ was purchased from Fluka (St Louis, MO). Fluo-4 NW was purchased from Life Technologies. Poly-D-lysine-coated 384-well plates were purchased from Falcon (Franklin Lakes, NJ). Polystyrene flatbottom plates were purchased from Greiner Bio-One (Frickenhausen, Germany). Cell-culture dishes $(60 \mathrm{~mm})$ were purchased from Corning (Corning, NY).

\section{Molecular cloning and cell-line generation}

Full length c-DNA sequences based on Genebank NM_007332 (human TRPA1) were cloned into the pT-REx-DEST vector for tetracycline-inducible expression in a human embryonic kidney 293 tetracycline inducible cell line (HEK293-T-REx) (Life Technologies). For continuous culturing, TRPA1HEK293-T-REx cells were grown as monolayers in medium (DMEM with GlutaMax, 10\% FCS) supplemented with $400 \mu \mathrm{g} / \mathrm{mL}$ G418 and $1 \mu \mathrm{g} / \mathrm{mL}$ blasticidin.

Chimeras of mouse and human TRPA1 were designed and synthesized by GeneArt ${ }^{\circledR}$ (Life Technologies). The most common full-length cDNA sequences for mouse (NM_177781) and human (NM_007332) were chosen. The wild-type (WT) mouse and the chimeric mouse cDNA constructs with human exons 19-23 (TM1-6) or exons 22 and 23 (TM5 and -6) were

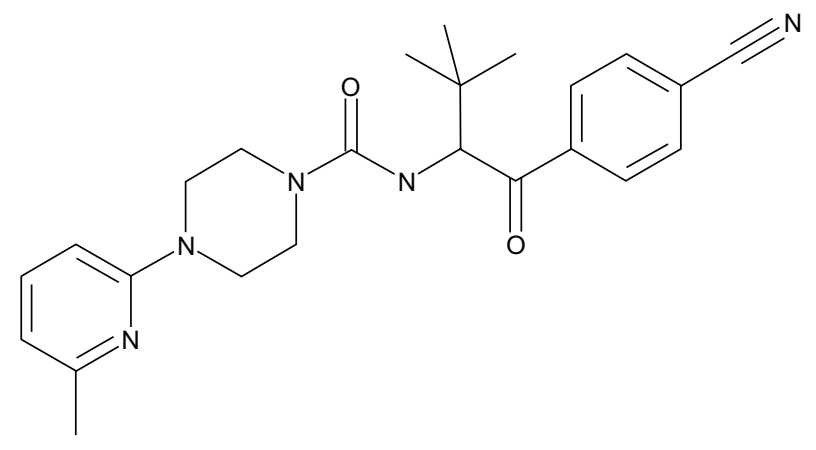

Figure I Chemical structure of AZ465. 
murine codon-optimized and subcloned into pcDNA4TO vector (Life Technologies) from a pMK GeneArt vector. More specifically, the human exons 19-23 insert sequence stars at amino acid 713 and end at amino acid 959, and the human exons 22 and 23 start at amino acid 855, ending at the same position. Numbers correspond to the full-length mouse sequence NM_177781.

All constructs were verified by DNA sequencing. HEK293T cells were transiently transfected (Lipofectamine 2000; Life Technologies) with the chimeric constructs 24-48 hours before the $\mathrm{Ca}^{2+}$ flux experiments.

\section{Calcium-influx experiments}

The calcium-influx measurements were done on a fluorescent imaging plate reader (FLIPR Tetra; Molecular Devices, Sunnyvale, CA). Stably expressing human TRPA1-HEK293T-REx cells or transiently transfected chimeric mouse/ human TRPA1-293T cells were resuspended in culture media (DMEM, 10\% FCS). TRPA1 protein expressions in the TRPA1-HEK293-T-REx cells were induced by adding $1 \mu \mathrm{g} / \mathrm{mL}$ doxycyclin to the medium. Cells were seeded in 384-well poly-D-lysine-coated plates and incubated for 24-48 hours at $37^{\circ} \mathrm{C}, 5 \% \mathrm{CO}_{2}$. Prior to the experiment, the medium was discarded and cells loaded with $25 \mu \mathrm{L}$ per well Fluo-4 NW in assay buffer (Hanks' balanced salt solution with $\mathrm{Ca}^{2+}$ and $\mathrm{Mg}^{2+}, 0.4 \% \mathrm{NaHCO} 3,10 \mathrm{mM}$ HEPES, pH 7.4) for 1 hour at room temperature. AZ465 and the various agonists (zinc chloride, CS, and cinnamaldehyde) were serial diluted in $100 \%$ dimethyl sulfoxide (DMSO) and further diluted in assay buffer. The final DMSO concentration did not exceed $0.3 \%$ in any experiment. Validation experiments showed that concentrations below $0.9 \%$ DMSO did not interfere with the assay. For the agonist concentration-response experiments, an initial baseline measurement was made for 10 seconds followed by addition of 10-15 concentrations of zinc chloride, CS, or cinnamaldehyde. The antagonistconcentration response was assessed in a two-addition protocol. After an initial 10-second baseline measurement period, the test compound (antagonist) was added to the cell plate and incubated online for 5 minutes before the addition of an $\mathrm{EC}_{70-80}$ concentration of agonist. Raw fluorescent counts were measured for 10 minutes after last addition. Excitation LED banks with wavelength 470-495 nm and emission filters with wavelength $515-575 \mathrm{~nm}$ were used.

\section{Patch-clamp recordings}

Human TRPA1-HEK293-TREx cells were seeded on poly-Dlysine-coated coverslips in culture media (DMEM, 10\% FCS) and induced with $1 \mu \mathrm{g} / \mathrm{mL}$ doxycyclin at $37^{\circ} \mathrm{C}$ and $5 \% \mathrm{CO}_{2}$. Cells were used for patch-clamp experiments 48 hours after induction.

Whole-cell currents were measured using an EPC10 amplifier (Heka, Lambrecht/Pfalz, Germany) at room temperature $\left(23^{\circ} \mathrm{C}\right)$. Pipette electrodes were made from borosilicate glass capillary tubes (GC150-10; Harvard Apparatus, Holliston, MA). The electrodes had resistances of 3-5 M when filled with internal solution. The cell membrane was clamped to a potential of $-80 \mathrm{mV}$ and a 1 -minute period was allowed to activate the TRPA1 channels after application of $250 \mu \mathrm{M}$ cinnamaldehyde in the bath solution after rupture of the membrane. TRPA1 current traces were recorded before application of AZ465, in the presence of $30 \mu \mathrm{M}$ AZ465, and after washout of AZ465. Between $50 \%$ and $80 \%$ of the series resistance was electronically compensated to minimize voltage errors, and currents were sampled at $10 \mathrm{kHz}$ and filtered at $0.2 \mathrm{kHz}$. The ramp protocol consisted of a $500 \mathrm{~ms}$ ramp from -80 to $+80 \mathrm{mV}$ from a holding potential of $0 \mathrm{mV}$ and was applied with a frequency of $1 \mathrm{~Hz}$. The protocol was controlled and data were analyzed with PatchMaster version 2.20 (Heka).

The extracellular solution contained (in mM) $147 \mathrm{NaCl}$, $4 \mathrm{KCl}, 10$ glucose, $10 \mathrm{HEPES}, 4 \mathrm{MgCl}_{2}$, and 5 EGTA, and the $\mathrm{pH}$ was adjusted to 7.4 with $\mathrm{NaOH}$. The intracellular solution contained (in mM) $120 \mathrm{CsCl}, 10$ EGTA, 10 HEPES, and $4 \mathrm{Na}_{3} \mathrm{GTP}$, and the $\mathrm{pH}$ was adjusted to 7.2 with $\mathrm{CsOH}$.

\section{Patients and ex vivo CGRP release from human dental pulp}

The study was performed in accordance with the ethical principles that have their origin in the Declaration of Helsinki and that are consistent with good clinical practice and applicable regulatory requirements. Informed consent was obtained from patients prior to tooth extraction. Males and nonpregnant females from 18 years old were included in the study. All patients had healthy and normal pulp. Patients with bad oral status, HIV/hepatitis B/C, or other medical reasons for not being eligible, as judged by the investigator, were not included in the study.

Patients were anesthetized using nerve-block local injection with 3-4 mL 2\% lidocaine/epinephrine. An ordinary surgical procedure was performed wherein a gingival flap was raised and bone was removed with a drill to get entrance for extraction of the tooth. The molar teeth where extracted or if necessary the crown was bisected from the roots with a drill before extraction. The coronal pulp was rapidly dissected and transferred to wells of a polypropylene 96-well plate 
containing ice-cold transplantation buffer (Aqix, London, UK). Each pulp was in turn divided in two or more parts ( 5-15 mg each).

The ex vivo method, based on release of CGRP from dental pulp biopsies, is described elsewhere. ${ }^{23}$ However, minor adaptations are described below. Basal- and agonist-evoked peripheral release of CGRP were analyzed in the absence and presence of experimental pharmacological compounds according to the following sequence: (1) after overnight incubation on ice, tissue was washed once with medium and incubated for 30 minutes at $37^{\circ} \mathrm{C}$; (2) the medium was changed, and samples for measurement of basal release were taken after 20 minutes; (3) 20-minute incubation with AZ465 or vehicle (solvent only) was followed by addition of agonist (final concentration, $200 \mu \mathrm{M}$ CS) for another 20 minutes and samples corresponding to control and inhibited levels were obtained; and finally (4) the pulp tissue was incubated with capsaicin $(50 \mu \mathrm{M}$, optimal concentration for maximal release $^{23}$ ) for normalization of the release and to verify the responsiveness of the tissue. The final concentration of DMSO in the dental pulp assay did not exceed $0.5 \%$. Tests made with dorsal root ganglion tissue showed that concentrations up to $1 \%$ DMSO did not result in altered CGRP release. Each sample was mixed with a $5 \times$ concentrate of EIA buffer (included in the kit) and frozen. The concentration of CGRP was measured by a commercial available immunoassay (SPI-Bio, Montigny le Bretonneux, France). In total, three samples were obtained from each piece of pulp tissue, and each pulp was used for analysis of control and at least one concentration of AZ465.

\section{Tissue processing and staining}

The presence of nociceptive markers of the dental pulp was analyzed by immunohistochemistry. Tissue was fixed in 4\% paraformaldehyde (HL96753.1000; Histolab, Gothenburg, Sweden) for 72 hours, dehydrated for 13 hours, and finally embedded in paraffin. The dental pulp paraffin blocks were sectioned into $4 \mu \mathrm{m}$-thick sections using a microtome (HM 355s; Microm Internationatal, Walldorf, Germany).

TRPA1 immunohistochemistry was performed on Ventana Discovery XT using OmniMap DAB (760-159; Ventana, Tucson, AZ) detection. The sections were deparaffinized in EZ prep (950-100; Ventana), and antigen retrieval was achieved by incubation with cell-conditioning solution 1 (950-124; Ventana), a Tris ethylenediaminetetraacetic acidbased buffer ( $\mathrm{pH} 7.8$ ), for 48 minutes at $95^{\circ} \mathrm{C}$. The TRPA1 (Frescati) antibody was diluted 1:100 $(4 \mu \mathrm{g} / \mathrm{mL})$ in antibody diluent (251-018; Ventana) and incubated for 60 minutes at room temperature. OmniMap anti-rabbit HRP-conjugated secondary antibody (760-4311; Ventana) was applied for 16 minutes at room temperature. The Frescati antibody was validated with Western blot and immunocytochemistry experiments on nontransfected and TRPA1-transfected HEK cells, as well as immunohistochemistry experiments on TRPA1-positive (tissue expressing TRPA1) and -negative (tissue not expressing TRPA1) tissue. Staining controls excluding primary and secondary antibody were also performed to exclude nonspecific staining (data not shown). The visualization was with 3,3'-diaminobenzidine (760-159; Ventana) incubated for 8 minutes at room temperature and counterstained with hematoxylin (760-2021; Ventana) for 4 minutes. Slides were dehydrated in ethanol and xylene and coverslipped in Eukitt (03989; Fluka).

\section{Data analysis}

In the calcium-influx experiments, inhibition and stimulation curves were analyzed by nonlinear regression analysis with variable slope on GraphPad Prism version 5.00 for Windows (GraphPad Software, La Jolla, CA) using the equation $\mathrm{Y}=$ bottom $+($ top - bottom $) /\left(1+10^{\left(\mathrm{LogIC}_{50}-\mathrm{X}\right)} \times\right.$ HillSlope).

The mean and standard error of three to six repeats at each concentration were plotted to obtain the half maximal effective concentration/half maximal inhibitory concentration $\left(\mathrm{EC}_{50} /\right.$ $\mathrm{IC}_{50}$ ) value. For agonist experiments, the data were normalized to the smallest and highest value for each data set. For antagonist experiments, the data were normalized to the response from the applied agonist $(100 \mu \mathrm{M}$ zinc or $10 \mathrm{nM} \mathrm{CS}$ or $50 \mu \mathrm{M}$ cinnamaldehyde) in the absence of the antagonist.

In the tooth-pulp model, CS-induced CGRP release, in the presence or absence of the TRPA1 antagonist AZ465, was expressed as a percentage of the capsaicin-evoked level minus the basal release, and compared to the level in control tissue from the same pulp. The data were analyzed using paired Student's $t$-test.

\section{Results}

\section{AZ465 potently and selectively inhibits the human TRPAI in vitro}

A FLIPR calcium-influx assay was used to determine the ability of AZ465 to inhibit human TRPA1 in vitro. Both $\mathrm{Zn}^{2+}$ and CS have been shown to be potent activators of human TRPA1. ${ }^{5,9}$ In our hands, $\mathrm{Zn}^{2+}$ and $\mathrm{CS}$ evoked a concentration-dependent $\mathrm{Ca}^{2+}$ influx with $\mathrm{EC}_{50}$ values of $3 \mu \mathrm{M}$ and $0.7 \mathrm{nM}$, respectively (data not shown). AZ465 appeared to be a very potent inhibitor of both $\mathrm{Zn}^{2+}(100 \mu \mathrm{M})$ - and 
CS (10 nM)-induced TRPA1 activation, with $\mathrm{IC}_{50}$ values of $85 \mathrm{nM}$ and $20 \mathrm{nM}$, respectively (Figure 2).

AZ465 displayed a high degree of selectivity for TRPA1. No effect of AZ465 up to $100 \mu \mathrm{M}$ could be observed on the responses of human TRPV1- and TRPM8-expressing cells to capsaicin or menthol, respectively (data not shown) (Table S1). Tested on a panel of $>100$ receptors, ion channels, nuclear hormone receptors, transporters, and enzymes (MDS Pharma Services) (Table S2), AZ465, at a concentration of $10 \mu \mathrm{M}$, did not interact significantly ( $\leq 50 \%$ inhibition or stimulation of binding), with most of the targets yielding a selectivity $>100$ fold for hTRPA1. Interaction was only observed with the dopamine transporter (DAT) $\left(K_{i}=3.02 \mu \mathrm{M}\right)$ and vasopressin $1_{\mathrm{A}}\left(\mathrm{V} 1_{\mathrm{A}}\right)$ receptor $\left(K_{i}=1.69 \mu \mathrm{M}\right)$, two targets with unlikely involvement in our test system (dental pulp).

\section{AZ465 binds reversibly in the transmembrane region of human TRPAI}

To further characterize AZ465, we generated two mTRPA1hTRPA1 chimeras where either the whole transmembrane domain (T1-T6) or the pore region (T5, T6) in the mouse TRPA1 channel was humanized (Figure 3 ). The generated chimeras were expressed in HEK-293T cells and assayed in a calcium-influx FLIPR assay. Transfection efficiency in transient expression systems is usually lower than in stably expressing cells, and consequently the fluorescent

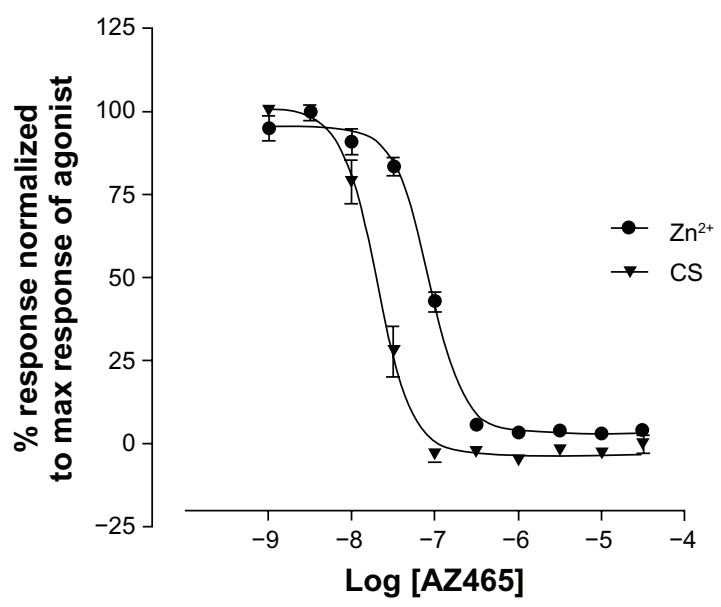

Figure 2 AZ465 is a potent inhibitor of $\mathrm{Zn}^{2+}$ and CS-induced TRPAI activation measured in a calcium-influx assay on FLIPR.

Notes: AZ465 inhibition of $\mathrm{Zn}^{2+-}$ and CS-induced intracellular $\mathrm{Ca}^{2+}$ increase (FLIPR) in HEK cells expressing the human TRPAI. AZ465 was added 5 minutes before addition of $100 \mu \mathrm{M}$ zinc chloride or $10 \mathrm{nM}$ CS. AZ465 fully inhibits the $\mathrm{Zn}^{2+-}$ and CS-induced activation with $\mathrm{IC}_{50}$ values of $85 \mathrm{nM}$ and $20 \mathrm{nM}$, respectively. Data are normalized to the maximum response of the agonist in the absence of AZ465 and represent the means \pm standard error of four or five measurements.

Abbreviations: CS, O-chlorobenzylidene malononitrile; FLIPR, fluorescent imaging plate reader; $I \mathrm{C}_{50}$, half maximal inhibitory concentration; TRPAI, transient receptor potential cation channel, member Al. response for the stable expressing cell line hTRPA1-WT was higher than for the three transiently transfected cell lines. Nevertheless, mTRPA1-WT, hTRPA-WT, and the two chimeras mTRPA1-hT1T6 and mTRPA1-hT5T6 were activated by cinnamaldehyde with similar $\mathrm{EC}_{50}$ values (Figure $4 \mathrm{~A}$ ), a response that could be blocked by the TRPA1 antagonist HC-030031, indicating that all constructs were functional (Figure 4C). When tested in these cell lines, AZ465 was able to block the cinnamaldehyde-induced response in the hTRPA1-WT ( IC $\left._{50} 305 \mathrm{nM}\right)$ but not in the mTRPA1-WT cells, in line with our observation that most of the compounds in AZ465's chemical series lost their activity going from human to rodent TRPA1. Interestingly, when the transmembrane domain (T1-T6) in the mouse channel was humanized (mTRPA1-hT1T6), AZ465 ability to block the cinnamaldehyde response was recovered ( $\left.\mathrm{IC}_{50} 370 \mathrm{nM}\right)$. Replacing only the pore region (T5, T6) of the mouse channel with the human one (mTRPA1-hT5T6) resulted in a similar recovery $\left(\mathrm{IC}_{50} 570 \mathrm{nM}\right)$ (Figure 4B), indicating that amino acid residues within the pore region of the hTRPA1 channel are critical for the binding of AZ465. This finding is in line with the result of a recent study where a homology model of TRPA1 based on Kv1.2 was used to identify residues available for interaction with ligands entering the pore vestibule. Site-directed mutation constructs were expressed in Xenopus oocytes and their functionality and pharmacology assessed to validate the homology model. Based on the results, an antagonist-binding site in the pore vestibule of the TRPA1 ion channel was suggested for compounds within AZ465's chemical series (Klement et al, unpublished data, 2012).

To investigate the reversibility of AZ465 binding on TRPA1, whole-cell patch-clamp experiments were performed. Application of $30 \mu \mathrm{M}$ AZ465 resulted in a rapid and complete inhibition of the cinnamaldehyde-activated TRPA1 currents, which recovered within seconds following washout (Figure 5).

Together, our findings suggest that (1) AZ465 binds to the transmembrane domain of the human TRPA1 channel, most likely the part that contains pore region; and (2) the mechanism ofTRPA1 inhibition by AZ465 does not involve the formation of strong covalent bonds with the ion-channel protein.

\section{AZ465 blocks CS-evoked CGRP release in human dental pulp ex vivo}

In this study, we explored the ability of AZ465 to block CGRP release evoked by the potent TRPA1 agonist CS in human tooth pulp ex vivo. CS, a compound used as a tear gas for riot control, has been shown to be $>100$-fold more potent 


\section{$\mathbf{N}$}

TM $1 \begin{array}{llllll}1 & 2 & 3 & 4 & 5 & 6\end{array}$

C

mTRPA1

hTRPA1

1111II

mTRPA1-hT5T6

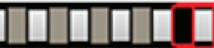

mTRPA1-hT1T6

Figure 3 Schematic drawing of the TRPAI constructs.

Notes: The transmembrane regions are indicated as TMI-6. The human sequences are indicated in red, both in the full-length and chimeric constructs. TMI-6 corresponds to exons 19-23 and TM5 and -6 to exons 22 and 23 . For detailed information, see materials and methods.

Abbreviations: CS, O-chlorobenzylidene malononitrile; TRPAI, transient receptor potential cation channel, member AI.

than cinnamaldehyde at gating TRPA1 in vitro, and they both do so by binding covalently in the cysteine-rich N-terminus. Because of its higher potency, CS was considered more suitable than cinnamaldehyde for ex vivo tissue experiments.

In total, 68 tooth-pulp samples were analyzed, corresponding to 33 teeth from 31 patients. In the first part of the study, the optimal concentration of CS was investigated. CS
$(1,10,25,50,100,200$, and $500 \mu \mathrm{M})$ caused a concentrationdependent increase in CGRP release that peaked at $200 \mu \mathrm{M}$. As a quality control of tissue responsiveness and viability and to normalize the data, $50 \mu \mathrm{M}$ of capsaicin was added to the preparation at the end of each experiment. All samples with capsaicin-induced responses below $50 \mathrm{pg}$ CGRP/mL were discarded, leaving 41 samples for further analysis.
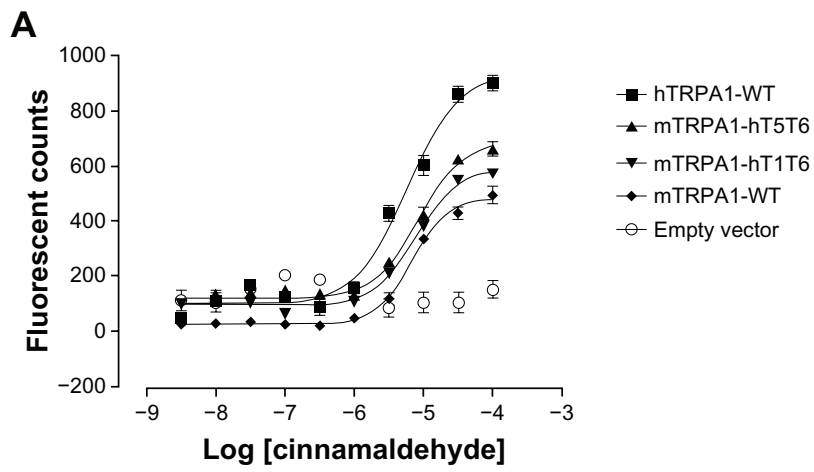

Empty vector

B

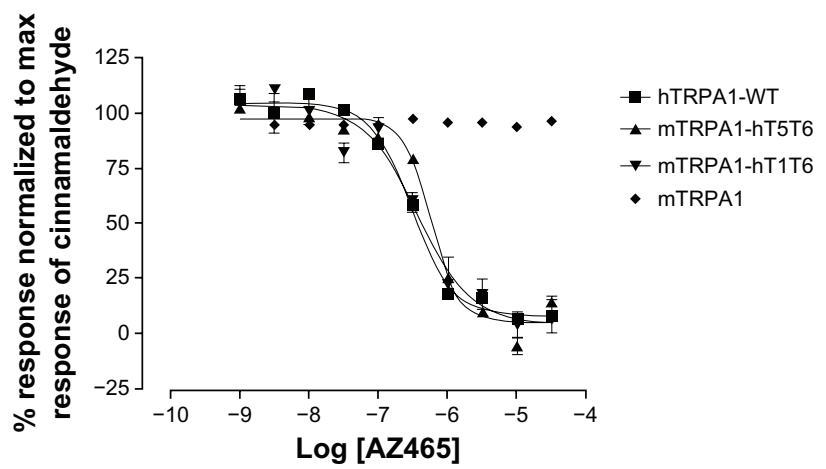

C

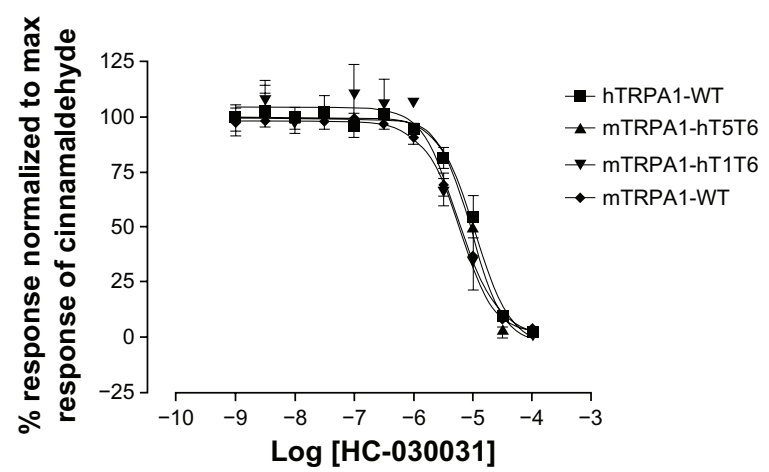

Figure 4 AZ465 inhibits cinnamaldehyde-induced TRPAI activation in hTRPAI and mouse/human chimeric TRPAI channels, but not in mTRPAI. (A) Agonist concentrationresponse curves for cinnamaldehyde on hTRPAI-WT, mTRPAI-hTIT6, mTRPAI-hT5T6, and mTRPAI-WT in a Ca ${ }^{2+-}$ influx assay. Cinnamaldehyde activates hTRPAI, mTRPAI-hTIT6, mTRPAI-hT5T6, and mTRPAI with similar half maximal effective concentration $\left(\mathrm{EC}_{50}\right)$ values $(6.8 \mu \mathrm{M}, 7.7 \mu \mathrm{M}, 8.5 \mu \mathrm{M}$, and 6.9 $\mu \mathrm{M}$, respectively). Data are plotted as peak fluorescent counts for each concentration and represent means \pm standard of four or five measurements. Antagonist concentration-response curves for AZ465 (B) and HC-03003I (C) against cinnamaldehyde (33 $\mu$ M)-induced TRPAI activation.

Note: AZ465 fully inhibits the activation in hTRPAI, mTRPAI-hTIT6, and mTRPAI-hT5T6 with half maximal inhibitory concentration (IC $_{50}$ values of 305 nM, 370 nM, and $570 \mathrm{nM}$, respectively, but AZ465 is inactive in the mTRPAI-WT cells. HC-03003I fully inhibits the activation in all cell lines, including mTRPAI-WT, with similar IC ${ }_{50}$ values (hTRPAI-WT, I0.5 $\mu \mathrm{M}$; mTRPAI-hTIT6, $5.5 \mu \mathrm{M}$; mTRPAI-hT5T6, $9.5 \mu \mathrm{M} ;$ mTRPAI-WT 6.5 $\mu \mathrm{M}$ ). Data are normalized to the maximum response evoked by $33 \mu \mathrm{M}$ cinnamaldehyde in the absence of AZ465 or HC-03003 I and represent the means \pm standard of four or five measurements.

Abbreviations: TRPAI, transient receptor potential cation channel, member AI; WT, wild type. 

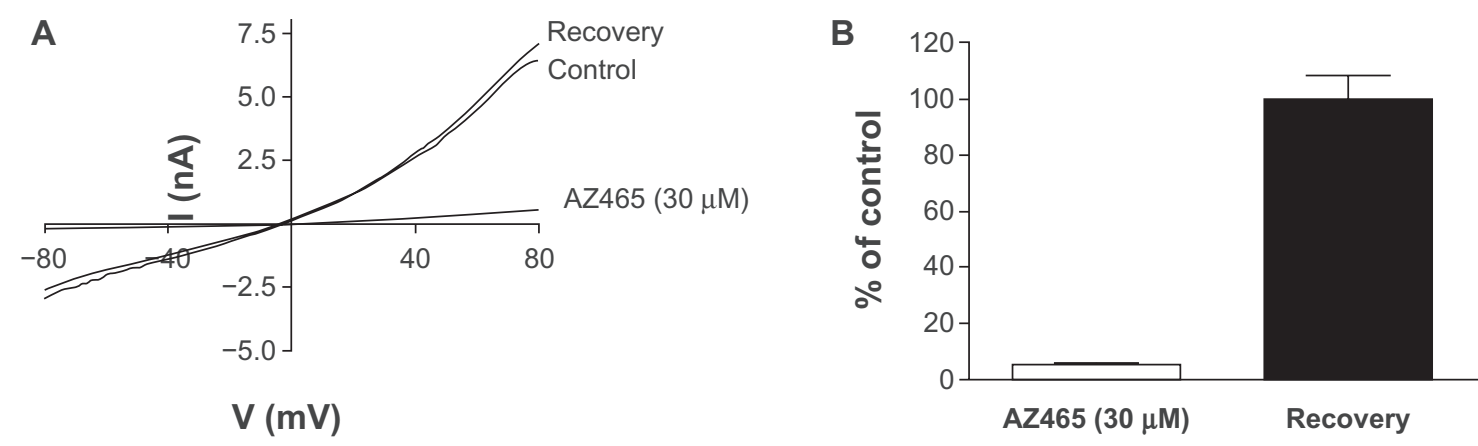

Figure 5 AZ465 reversibly inhibits cinnamaldehyde-activated TRPAI currents in whole-cell patch-clamp experiments. (A) Cinnamaldehyde-activated TRPAI current traces in response to a voltage ramp $\left(-80 \mathrm{mV}\right.$ to $+80 \mathrm{mV}$ in $500 \mathrm{~ms}, \mathrm{~V}_{\text {hold }}=0 \mathrm{mV}$ ) before application of AZ465 (control), in the presence of $30 \mu \mathrm{M}$ AZ465 (AZ465), and after washout of AZ465 (recovery). (B) Time course of steady-state cinnamaldehyde-activated TRPAI current amplitudes measured at $+80 \mathrm{mV}$ showing the reversible effect of repeated application and washout of AZ465. (C) AZ465 reduces the cinnamaldehyde-activated TRPAI current to $5.4 \% \pm 1.7 \%$ of the control current ( $n=3$, white bar). Note: Washout of AZ465 leads to a full recovery of the TRPAI response, with current amplitudes reaching $99.6 \% \pm 8.9 \%$ of the control current $(n=3$, black bar). Abbreviations: TRPAI, transient receptor potential cation channel, member AI; WT, wild type.

AZ465 (10 and $50 \mu \mathrm{M})$ produced a significant inhibition of CS-evoked CGRP release in human dental pulp (Figure 6). The higher concentration $(50 \mu \mathrm{M})$ of AZ465 was tested in six different individuals and resulted in an average $\sim 2.5$ fold reduction of CGRP release $(P=0.003$, paired $t$-test). Application of $10 \mu \mathrm{M}$ of AZ465 resulted in a $\sim 2.0$-fold reduction of CGRP release ( $P=0.011, \mathrm{n}=4$, paired $t$-test).

Also, the expression of TRPA1 in dental pulp samples was verified using immunohistochemistry (Figure 7). Our data confirm the expression of TRPA1 in human dental pulp, with immunopositive cells more frequently expressed in the peripheral parts of the tissue, in line with a recent report. ${ }^{22}$

\section{Discussion}

In this paper, we have provided evidence that the novel compound AZ465 is a potent and selective TRPA1 antagonist with activity in native human tissue.

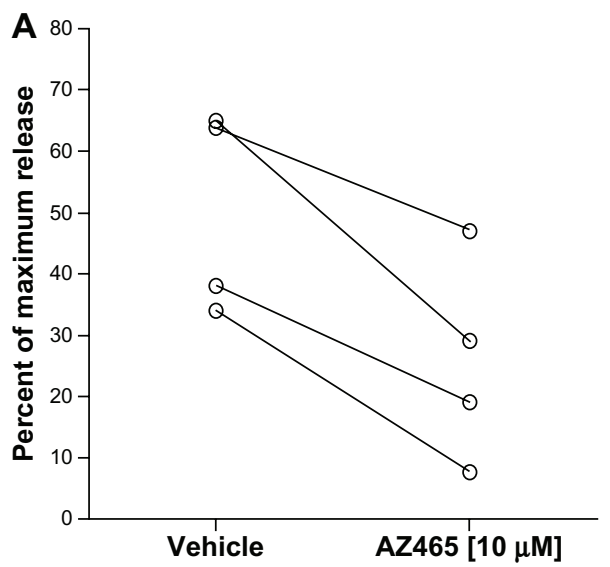

In vitro, as measured in a $\mathrm{Ca}^{2+}$ flux assay, AZ465 fully inhibited the TRPA1 response to cinnamaldehyde and CS, two highly electrophilic compounds that activate hTRPA1 through covalent cysteine binding. ${ }^{9,26,28}$ AZ465 also fully inhibited TRPA 1 activation by $\mathrm{Zn}^{2+}$, which most likely occurs via a different mechanism involving interaction with an intracellular C-terminal site. ${ }^{5,27}$ The $\mathrm{IC}_{50}$ values for AZ465 varied somewhat depending on the agonist $(30 \pm 10 \mathrm{nM}$ vs $\mathrm{CS}, 85 \pm 20 \mathrm{nM}$ vs $\mathrm{Zn}^{2+}, 305 \pm 65 \mathrm{nM}$ vs cinnamaldehyde, mean \pm standard error, $n=4$ ). One possible contributing factor was that the concentrations of the agonists used in the assay were an estimation of their $\mathrm{EC}_{70-80}$ and even though our data show that AZ465 binds in the transmembrane region of the channel, suggesting a noncompetitive interaction between AZ465 and the agonists, some shift in the inhibition doseresponse curve for AZ465 depending on the agonist concentration could nonetheless be seen for cinnamaldehyde

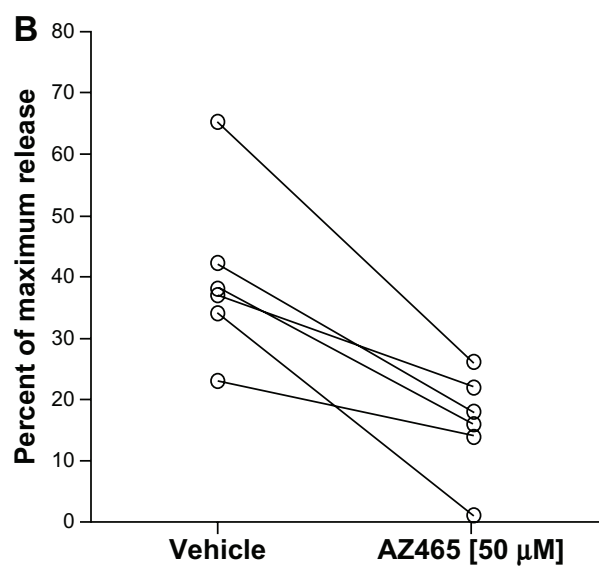

Figure 6 Significant inhibition of CS-evoked CGRP release in human dental pulp by AZ465. Each pair of samples represents data from one pulp. Data from ten individuals are shown. Release of CGRP was expressed as percentage of maximum release obtained by capsaicin minus basal release from the tissue. The concentration of CS was 200 $\mu M$ in all experiments; the concentrations of $A Z 465$ were $10 \mu M(\mathbf{A})$ and $50 \mu M(B)$.

Abbreviations: CGRP, calcitonin gene-related peptide; CS, $O$-chlorobenzylidene malononitrile. 


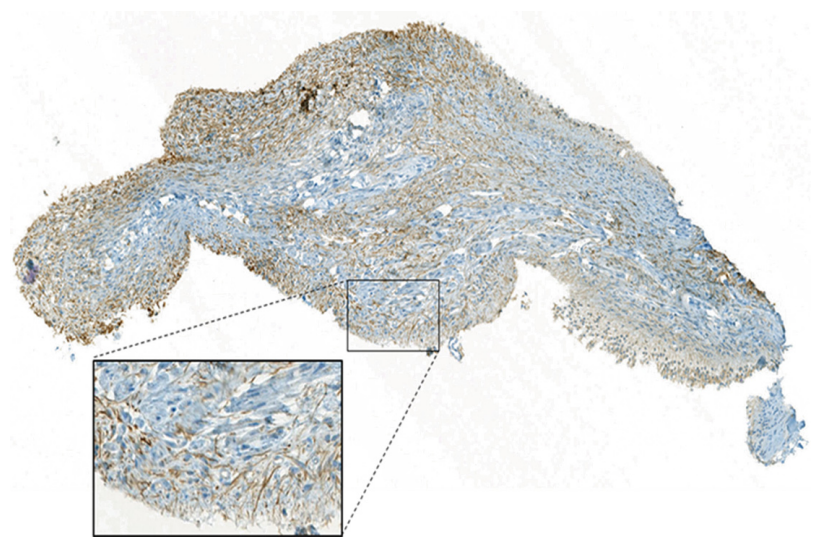

Figure 7 TRPAI immunohistochemistry in dental pulp.

Note: Representative image showing the expression patterns of TRPAI (brown) in the human coronal dental pulp.

Abbreviation: TRPAI, transient receptor potential cation channel, member AI.

and CS (data not shown). Still, our results indicate that AZ465 is effective in blocking TRPA1 regardless of the gating modality. AZ465 also appeared to be highly selective for human TRPA1, with no affinity for hTRPM8, hTRPV1, or 104 of the 106 other molecular targets tested, with only moderate affinity for two - DAT and $\mathrm{V} 1_{\mathrm{A}}$ - to our knowledge not expressed in peripheral sensory neurons.

Using patch-clamp experiments and mouse/human TRPA1 chimeras, we were able to demonstrate that AZ465 binds reversibly to the pore region (T5, T6) of the human but not the mouse (or the rat, data not shown) channel. This finding is not surprising considering the limited sequence identity between human and rodent TRPA1 proteins (about $80 \%$ ). Also, amino acids in the T5/T6 region are known to play a key role in mediating the response of TRPA1 to pharmacological tools. For instance, the electrophilic antagonist CMP1 acted as an agonist when the pore region (T5, T6) of the human protein was exchanged for the rat sequence. Conversely, CMP1 acted as an antagonist at the rat TRPA1 when the pore region was "humanized," specific residues in T6 being critical for the difference. ${ }^{29}$ Similarly, key residues in the T5 region of TRPA1 point towards this region as the critical domain for the antagonistic action of menthol. ${ }^{21}$

Given that discrete variations in amino acid sequence may be responsible for pharmacological and functional differences between TRPA1 orthologs, confirming the pharmacological activity of compounds in native human tissue is essential in a drug-discovery program. Therefore, we have developed an ex vivo pharmacodynamic model using human dental pulp to characterize our TRPA1 antagonists.

Previously, capsaicin had been shown to evoke CGRP release in a human dental pulp preparation, a response that could be fully inhibited by the TRPV1 antagonist capsazepine. ${ }^{23}$ Using an adaptation of the method, we show here that CS triggers the release of CGRP from human dental pulp biopsies, a response that could be reduced by AZD465, indicating its ability to inhibit the native human TRPA1 channel.

Even though CS is a very potent TRPA1 activator on recombinant TRPA1 cells in vitro, micromolar concentrations were needed to elicit a robust CGRP release in the pulp. It is indeed a common observation that when going from a cell culture to a complex tissue, higher concentrations of a ligand are required to evoke a pharmacological response. For instance, in the same preparation, micromolar concentrations of the TRPV1 agonist capsaicin were needed to trigger the release of neuropeptides $\left(\mathrm{EC}_{50} \sim 20 \mu \mathrm{M}\right){ }_{,}^{23}$ although capsaicin is a far more potent TRPV1 activator in vitro in cell preparations with an $\mathrm{EC}_{50}$ in the low nanomolar range. ${ }^{30}$ In our dental pulp preparation, $10 \mathrm{mM}$ of cinnamaldehyde (maximum concentration in an acceptable vehicle) triggered only low levels of CGRP release (data not shown), and CS was selected instead.

Another observation was that the CGRP release was only reduced by $50 \%-60 \%$ at the highest concentration of AZ465. Several explanations may account for this partial inhibition. CS is a reactive compound like most of the known TRPA1 agonists, activating the channel through chemical reactivity of their electrophilic groups with cysteine residues in the protein, and as such it can readily react with nucleophilic sites in different enzymes and other proteins. ${ }^{31}$ Therefore, it cannot be excluded that at the concentrations used here, CS reacts with other targets, of which some could trigger a downstream CGRP release independent of TRPA1, and as such, is insensitive to AZ465. Also, as discussed above for CS, the effective concentration of AZ465 that actually reached TRPA1 within the complex, nondissociated pulp tissue was most likely lower than the concentrations (10 and $50 \mu \mathrm{M})$ applied to the preparation. Like many drug-like small molecules, AZ465 binds nonspecifically to other proteins, like albumin, present in blood and tissues (AZ465 plasma protein binding $\sim 98 \%$, data not shown) reducing the free fraction available for interaction with TRPA1. Due to AZ465's limited water solubility, testing higher concentrations than $50 \mu \mathrm{M}$ to address whether CGRP release could be fully blocked was not feasible in an acceptable vehicle.

Finally, another possible hypothesis for the partial inhibition could be that the native target expressed in the human dental pulp is different from the recombinant TRPA1 expressed in the HEK cells, and that AZ465 doesn't fully block native TRPA1 activation. Structurally, TRPA1 
are tetramers and form homo- or heteromeric complexes. For instance, TRPA1 has been reported to colocalize with TRPV $1^{1,32}$ in dorsal root ganglia and trigeminal neurons. Functionally, it has been demonstrated that coexpression of TRPA1 with TRPV1 alters single-channel properties for AITC as well as the pharmacology for TRPA1 agonists and antagonists. ${ }^{2,32,33}$ It cannot be excluded that such crossmodulation of TRPA1 biophysical and regulatory properties or other post translational modifications could alter the pharmacology of AZ465 in native tissue as compared to the pharmacology in a recombinant system.

In summary, although additional studies using alternative agonists and antagonists, prolonged incubation times, etc, are necessary to complete its validation, the dental pulp model is a promising approach for testing the pharmacology of TRPA1 antagonists at the native human channel.

\section{Conclusion}

AZ465 is a novel, potent, selective, and fully reversible inhibitor of human TRPA1 in in vitro recombinant systems and is also active on the native human TRPA1. Our model of CS-induced CGRP release from human dental pulp represents a promising translational tool for the pharmacological characterization of TRPA1 antagonists in human native tissue.

\section{Acknowledgment}

The authors thank Dr Steven England for sharing his vast knowledge of ion channel science and for his guidance.

\section{Disclosure}

The authors report no conflicts of interest in this work.

\section{References}

1. Kobayashi K, Fukuoka T, Obata K, et al. Distinct expression of TRPM8, TRPA1, and TRPV1 mRNAs in rat primary afferent neurons with adelta/c-fibers and colocalization with trk receptors. J Comp Neurol. 2005;493:596-606.

2. Salas M, Hargreaves K, Akopian A. TRPA1-mediated responses in trigeminal sensory neurons: interaction between TRPA1 and TRPV1. Eur J Neurosci. 2009;29:1568-1578.

3. Story G, Peier A, Reeve A, et al. ANKTM1, a TRP-like Channel expressed in nociceptive neurons, is activated by cold temperatures. Cell. 2003;112:819-829.

4. Doerner JF, Gisselmann G, Hatt H, Wetzel CH. Transient receptor potential channel A1 is directly gated by calcium ions. Biol Chem. 2007;282:13180-13189.

5. Hu H, Bandell M, Petrus MJ, Zhu MX, Patapoutian A. Zinc activates damage-sensing TRPA1 ion channels. Nat Chem Biol. 2009;5:183-190.

6. Jordt, SE, Bautista DM, Chuang HH, et al. Mustard oils and cannabinoids excite sensory nerve fibres through the TRP channel ANKTM1. Nature. 2004;427:260-265.

7. Bandell M, Story GM, Hwang SW, et al. Noxious cold ion channel TRPA1 is activated by pungent compounds and bradykinin. Neuron. 2004;41:849-857.
8. Macpherson LJ, Geierstanger BH, Viswanath V, et al. The pungency of garlic: activation of TRPA1 and TRPV1 in response to allicin. Curr Biol. 2005; 15:929-934.

9. Brône B, Peeters PJ, Marrannes R, et al. Tear gasses CN, CR, and CS are potent activators of the human TRPA1 receptor. Toxicol Appl Pharmacol. 2008;231:150-156.

10. Radresa O, Dahllöf H, Nyman E, et al. TRPA1 in pain pathophysiology and implications for the development of a new class of analgesic drugs. Open Pain J. In press; 2012.

11. Trevisani M, Siemens J, Materazzi S, et al. 4-hydroxynonenal, an endogenous aldehyde, causes pain and neurogenic inflammation through activation of the irritant receptor TRPA1. Proc Natl Acad Sci U S A. 2007;104:13519-13524.

12. Sawada Y, Hosokawa H, Matsumura K, Kobayashi S. Activation of transient receptor potential ankyrin 1 by hydrogen peroxide. Eur $J$ Neurosci. 2008;27:1131-1142.

13. Taylor-Clarke TE, Ghatta S, Bettner W, Undem BJ. Nitrooleic ocid, an endogenous product of nitrative stress, activates nociceptive sensory neurons via the direct activation of TRPA1. Mol Pharmacol. 2009; 75:820-829.

14. Petrus M, Peier AM, Bandell M, et al. A role of TRPA1 in mechanical hyperalgesia is revealed by pharmacological inhibition. Mol Pain. 2007;3:40

15. Eid SR, Crown ED, Moore EL, et al. HC-030031, a TRPA1 selective antagonist, attenuates inflammatory- and neuropathy-induced mechanical hypersensitivity. Mol Pain. 2008;4:48.

16. Fernandes ES, Russell FA, Spina D, et al. A distinct role for transient receptor potential ankyrin 1, in addition to transient receptor potential vanilloid 1 , in tumor necrosis factor alpha-induced inflammatory hyperalgesia and Freund's complete adjuvant-induced monarthritis. Arthritis Rheum. 2011;63:819-829.

17. McGaraughty S, Chu KL, Perner RJ, Didomenico S, Kort ME, Kym PR. TRPA1 modulation of spontaneous and mechanically evoked firing of spinal neurons in uninjured, osteoarthritic, and inflamed rats. Mol Pain. 2010;6:14

18. Kremeyer B, Lopera F, Cox JJ, et al. A gain-of-function mutation in TRPA1 causes familiar episodic pain syndrome. Neuron. 2010;66: 671-680.

19. Klionsky L, Tamir R, Gao B, et al. Species-specific pharmacology of Trichloro(sulfanyl)ethyl benzamides as transient receptor potential ankyrin 1 (TRPA1) antagonists. Mol Pain. 2007;3:39.

20. Nagatomo K, Ishii H, Yamamoto T, Nakajo K, Kubo Y. The Met268Pro mutation of mouse TRPA 1 changes the effect of caffeine from activation to suppression. Biophys J. 2010;99:3609-3618.

21. Xiao B, Dubin AE, Bursulaya B, Viswanath V, Jegla TJ, Patapoutian A. Identification of transmembrane domain 5 as a critical molecular determinant of menthol sensitivity in mammalian TRPA1 channels. J Neurosci. 2008;28:9640-9651.

22. Kim YS, Jung HK, Kwon TK, et al. Expression of transient receptor potential ankyrin in human dental pulp. J Endod. 2012;38:1087-1092.

23. Fehrenbacher JC, Sun XX, Locke EE, Henry MA, Hargreaves KM. Capsaicin-evoked iCGRP release from human dental pulp: a model system for the study of peripheral neuropeptide secretion in normal healthy tissue. Pain. 2009;144:253-261.

24. Kunkler PE, Ballard CJ, Oxford GS, Hurley JH. TRPA1 receptors mediate environmental irritant-induced meningeal vasodilatation. Pain 2011;152:38-44.

25. Weigelt D, Svensson M. TRPA1 receptor antagonist. Patent application WO2012050512. April 19, 2012.

26. Bessac BF, Sivula M, von Hehn CA, Caceres AI, Escalera J, Jordt SE. Transient receptor potential ankyrin 1 antagonists block the noxious effects of toxic industrial isocyanates and tear gases. FASEB $J$. 2009;23:1102-1114.

27. Banke TG, Wickenden AD. Intracellular zinc irritates TRPA1. Nat Chem Biol. 2009;5:141-142.

28. Macpherson LJ, Dubin AE, Evans MJ, et al. Noxious compounds activate TRPA1 ion channels through covalent modifications of cysteines. Nature. 2007;445:541-545. 
29. Chen J, Zhang XF, Kort ME, et al. Molecular determinants of speciesspecies activation or blockade of TRPA1 channels. J Neurosci. 2008;28:5063-5071.

30. Alexander SPH, Mathie A, Peters JA. Guide to Receptors and Channels (GRAC). 5th ed. Br J Pharmacol. 2011;164 Suppl 1:S1-S324.

31. Blain PG. Tear gases and irritant incapacitants 1-chloroacetophenone, 2-chlorobenzylidene malononitrileand dibenz[B,F]-1,4-oxazepine. Toxicol Rev. 2003;22:103-110.
32. Staruschenko A, Jeske NA, Akopian AN. Contribution of TRPA1TRPV1 interaction to the single channel properties of the TRPA1 channel. J Biol Chem. 2010;285:15167-15177.

33. Akopian AN. Nociceptive transmission at the periphery via TRPA1TRPV1 interactions. Curr Pharm Biotechnol. 2011;12:89-94. 


\section{Supplementary materials}

Table SI Selectivity targets tested at AstraZeneca at concentration $100 \mu \mathrm{M}$

\begin{tabular}{lll}
\hline Ligand-gated ion channels & TRPVI & Rat \\
Ligand-gated ion channels & TRPVI & Human \\
Ligand-gated ion channels & TRPM8 & Human \\
Enzymes & Prostaglandin E & Human \\
& synthases I (PGESI) & \\
Voltage-gated ion channels & NaVI.7 & Human \\
\hline
\end{tabular}

Table S2 Selectivity targets tested at MDS Pharma Services at concentration $10 \mu \mathrm{M}$

\begin{tabular}{|c|c|c|}
\hline Target class & Target & Species \\
\hline Enzymes & Monoamine oxidase, MAOA & Human \\
\hline Enzymes & $\begin{array}{l}\text { Nitric oxide synthase, } \\
\text { endothelial eNOS }\end{array}$ & Bovine \\
\hline Enzymes & Angiotensin converting enzyme & Rabbit \\
\hline Enzymes & Acetylcholinesterase & Human \\
\hline Enzymes & Aldose reductase & Rat \\
\hline Enzymes & Cathepsin B & Human \\
\hline Enzymes & Matrix metalloproteinase (MMP)-2 & Human \\
\hline Enzymes & Cyclooxygenase, COX-2 & Human \\
\hline Enzymes & Cyclooxygenase, COX-I & Human \\
\hline Enzymes & Renin & Human \\
\hline Enzymes & Phosphodiesterase PDE 3 & Human \\
\hline Enzymes & Thrombin & Human \\
\hline Enzymes & ATPase, $\mathrm{Na}+/ \mathrm{K}+$ & Porcine \\
\hline Enzymes & MMP-14 & Human \\
\hline Enzymes & Caspase I & Human \\
\hline Enzymes & $\begin{array}{l}\text { Peptidase, endothelin } \\
\text { converting enzyme (ECE)-I }\end{array}$ & Human \\
\hline Enzymes & $\begin{array}{l}\text { Protein tyrosine } \\
\text { phosphatase, PTPRC }\end{array}$ & Human \\
\hline Enzymes & $\begin{array}{l}\text { Nitric oxide synthase, } \\
\text { endothelial eNOS }\end{array}$ & Bovine \\
\hline Enzymes & Carbonic anhydrase II & Human \\
\hline GPCR & Opiate, delta (OPI, DOP) & Human \\
\hline GPCR & Opiate, mu (OP3, MOP) & Human \\
\hline GPCR & Opiate, kappa (OP2, KOP) & Human \\
\hline GPCR & Adrenergic, beta2 & Human \\
\hline GPCR & Cannabinoid, CB2 & Human \\
\hline GPCR & Adenosine, A2A & Human \\
\hline GPCR & Adrenergic, alpha IA & Rat \\
\hline GPCR & Adenosine, Al & Human \\
\hline GPCR & Adenosine, $\mathrm{A} 3$ & Human \\
\hline GPCR & Adrenergic, alpha2A & Human \\
\hline GPCR & Adrenergic, betal & Human \\
\hline GPCR & Adrenergic, alpha2B & Human \\
\hline GPCR & Endothelin, ETA & Human \\
\hline GPCR & Dopamine, D4.2 & Human \\
\hline GPCR & Dopamine, D2L & Human \\
\hline GPCR & Dopamine, DI & Human \\
\hline GPCR & Cholecystokinin CCK2 (CCKB) & Human \\
\hline GPCR & Serotonin, 5-HT4 & $\begin{array}{l}\text { Guinea } \\
\text { pig }\end{array}$ \\
\hline
\end{tabular}

Table S2 (Continued)

\begin{tabular}{|c|c|c|}
\hline Target class & Target & Species \\
\hline$\overline{\mathrm{GPCR}}$ & Prostanoid, thromboxane A2 & Human \\
\hline GPCR & Histamine, $\mathrm{H} 2$ & Human \\
\hline GPCR & Chemokine CXCR2 (IL-8B) & Human \\
\hline GPCR & Cysteinyl CysLTI & Human \\
\hline GPCR & Melanocortin MC4 & Human \\
\hline GPCR & Motilin & Human \\
\hline GPCR & Muscarinic, M2 & Human \\
\hline GPCR & Muscarinic, M3 & Human \\
\hline GPCR & Neuropeptide, YI & Human \\
\hline GPCR & Serotonin, 5-HTIA & Human \\
\hline \multirow[t]{2}{*}{ GPCR } & Serotonin (5-hydroxytryptamine) & Human \\
\hline & 5-HT2A & \\
\hline \multirow[t]{2}{*}{ GPCR } & Serotonin (5-hydroxytryptamine) & Human \\
\hline & 5-HT2B & \\
\hline GPCR & Vanilloid & Rat \\
\hline GPCR & Platelet activating factor (PAF) & Human \\
\hline \multirow[t]{2}{*}{ GPCR } & Growth hormone & Human \\
\hline & secretagogue (GHS, Ghrelin) & \\
\hline GPCR & Histamine, $\mathrm{HI}$ & Human \\
\hline GPCR & Bombesin BB2 & Human \\
\hline GPCR & Adrenergic, alpha ID & Human \\
\hline GPCR & $\begin{array}{l}\text { Gamma-aminobutyric acid } \\
\text { (GABA) Bla }\end{array}$ & Human \\
\hline GPCR & Melatonin receptor IA, MTI & Human \\
\hline GPCR & Serotonin, 5-HTIB & Rat \\
\hline GPCR & Cholecystokinin CCKI (CCKA) & Human \\
\hline GPCR & Somatostatin sst 4 & Human \\
\hline GPCR & Cannabinoid, CBI & Human \\
\hline GPCR & Chemokine, CCRI & Human \\
\hline GPCR & Adenosine, $\mathrm{A} 2 \mathrm{~A}$ & Human \\
\hline GPCR & Bradykinin, B2 & Human \\
\hline GPCR & $\begin{array}{l}\text { Calcitonin gene-related } \\
\text { peptide CGRPI }\end{array}$ & Human \\
\hline GPCR & Tachykinin, NKI & Human \\
\hline GPCR & Neurotensin receptor I & Human \\
\hline GPCR & Leukotriene B4 receptor & Human \\
\hline GPCR & $\mathrm{P} 2 \mathrm{Y}$ purine receptor & Rat \\
\hline Kinases & $\begin{array}{l}\text { Rho-associated, coiled-coil containing } \\
\text { protein kinase I (ROCKI) }\end{array}$ & Human \\
\hline Kinases & $\begin{array}{l}\text { Fibroblast growth factor receptor I } \\
\text { (FGFRI) }\end{array}$ & Human \\
\hline Kinases & $\begin{array}{l}\text { Vascular endothelial growth factor } \\
\text { (VEGFR), cFit }\end{array}$ & Human \\
\hline Kinases & $\begin{array}{l}\text { Hepatocyte growth factor receptor } \\
\text { (HGFR) (cMet) }\end{array}$ & Human \\
\hline Kinases & Tyrosine-protein kinase Yes & Human \\
\hline Kinases & $\begin{array}{l}\text { Epidermal growth factor receptor } \\
\text { (EGFR) }\end{array}$ & Human \\
\hline Kinases & Insulin receptor & Human \\
\hline Kinases & Sarcoma (Src) & Human \\
\hline Kinases & Fyn-related kinase (Fyn) & Human \\
\hline Ligand-gated & Nicotinic acetylcholine & Human \\
\hline ion channels & & \\
\hline
\end{tabular}


Table S2 (Continued)

\begin{tabular}{|c|c|c|}
\hline Target class & Target & Species \\
\hline $\begin{array}{l}\text { Ligand-gated } \\
\text { ion channels }\end{array}$ & Glycine, strychnine-sensitive & Rat \\
\hline $\begin{array}{l}\text { Ligand-gated } \\
\text { ion channels }\end{array}$ & Glutamate, NMDA, agonism & Rat \\
\hline $\begin{array}{l}\text { Ligand-gated } \\
\text { ion channels }\end{array}$ & $\begin{array}{l}\text { Glutamate, NMDA, } \\
\text { phencyclidine }\end{array}$ & Rat \\
\hline $\begin{array}{l}\text { Ligand-gated } \\
\text { ion channels }\end{array}$ & Glutamate, NMDA, glycine & Rat \\
\hline $\begin{array}{l}\text { Ligand-gated } \\
\text { ion channels }\end{array}$ & Serotonin, 5-HT3 & Human \\
\hline $\begin{array}{l}\text { Ligand-gated } \\
\text { ion channels }\end{array}$ & $\begin{array}{l}\text { GABAA, benzodiazepine, } \\
\text { central }\end{array}$ & Rat \\
\hline Nuclear receptors & Estrogen, ERa & Human \\
\hline Nuclear receptors & Testosterone & Rat \\
\hline Nuclear receptors & Progesterone PRB & Human \\
\hline Nuclear receptors & Glucocorticoid & Human \\
\hline $\begin{array}{l}\text { Nuclear } \\
\text { receptors }\end{array}$ & Retinoid X receptor $\mathrm{RXRa}$ & Human \\
\hline $\begin{array}{l}\text { Other } \\
\text { receptors }\end{array}$ & Sigma I & Human \\
\hline $\begin{array}{l}\text { Other } \\
\text { receptors }\end{array}$ & Benzodiazepine, peripheral & Rat \\
\hline $\begin{array}{l}\text { Receptor } \\
\text { tyrosine kinases }\end{array}$ & Epidermal growth factor & Human \\
\hline Transporters & Adenosine transporter & $\begin{array}{l}\text { Guinea } \\
\text { pig }\end{array}$ \\
\hline Transporters & Noradrenaline transporter & Human \\
\hline Transporters & Dopamine transporter & Human \\
\hline Transporters & Serotonin transporter & Human \\
\hline $\begin{array}{l}\text { Voltage-gated } \\
\text { ion channels }\end{array}$ & KATP channel & Hamster \\
\hline $\begin{array}{l}\text { Voltage-gated } \\
\text { ion channels }\end{array}$ & $\begin{array}{l}\text { Calcium channel, } \\
\text { L-type, dihydropyridine }\end{array}$ & Rat \\
\hline $\begin{array}{l}\text { Voltage-gated } \\
\text { ion channels }\end{array}$ & $\begin{array}{l}\text { Calcium channel, } \\
\text { L-type, benzothiazepine }\end{array}$ & Rat \\
\hline $\begin{array}{l}\text { Voltage-gated } \\
\text { ion channels }\end{array}$ & $\begin{array}{l}\text { Human ether-à-go-go-related gene } \\
\text { (hERG) }\end{array}$ & Human \\
\hline $\begin{array}{l}\text { Voltage-gated } \\
\text { ion channels }\end{array}$ & $\mathrm{NaVI} .5$ & Human \\
\hline $\begin{array}{l}\text { Voltage-gated } \\
\text { ion channels }\end{array}$ & Ito Kv4.3 potasssium channel & Human \\
\hline $\begin{array}{l}\text { Voltage-gated } \\
\text { ion channels }\end{array}$ & IKs potassium channel & Human \\
\hline $\begin{array}{l}\text { Voltage-gated } \\
\text { ion channels }\end{array}$ & $\mathrm{CaN} \mathrm{N}$-type calcium channel & Rat \\
\hline
\end{tabular}

\section{Journal of Pain Research}

\section{Publish your work in this journal}

The Journal of Pain Research is an international, peer-reviewed, open access, online journal that welcomes laboratory and clinical findings in the fields of pain research and the prevention and management of pain. Original research, reviews, symposium reports, hypothesis formation and commentaries are all considered for publication.

The manuscript management system is completely online and includes a very quick and fair peer-review system, which is all easy to use. Visit http://www.dovepress.com/testimonials.php to read real quotes from published authors. 